\title{
RATZINGER, Joseph. L'elogio della coscienza: la verità interroga il cuore. Siena: Cantagalli, 2009.
}

Rodrigo Coppe Caldeira

Para se compreender um pontificado, nada melhor do que ler os documentos dele emanados. E quando se tem um papa intelectual, nada melhor do que ler a sua obra propriamente. Joseph Ratzinger já publicou dezenas de livros, apresentando suas perspectivas eclesiológicas, filosóficas e históricas. O último é L’elogio della coscienza: la verità interroga il cuore, publicado na Itália em 2009.

Nessa obra, Bento XVI apresenta uma reflexão sobre a consciência, a verdade, a evangelização e o papado, apoiando-se nos pensamentos de Sócrates e John Henry Newmann (beatificado em sua viagem à Grã-Bretanha), além de explicitar noções polêmicas em excesso para aqueles que o veem como um bastião da "reação católica" como a da "ditadura do relativismo". De fato, essa temática aparece recorrentemente em seus textos. Desde quando presidia a Sagrada Congregação para a Doutrina da Fé, Ratzinger criticava o estado espiritual do Ocidente contemporâneo, como se pode ver em Fé, Verdade e Tolerância: o cristianismo e as religiões do mundo, publicado em 2003 - no Brasil, em 2007, pela editora Raimundo Lulio.

O relativismo ético, que também tem seus reflexos no campo teológico, parece ser uma das principais batalhas de Bento XVI, juntamente com a busca de uma hermenêutica para o Vaticano II. Em meio à descrença generalizada em qualquer tipo de discurso como possível portador de verdade e significados universalizantes, Bento XVI torna-se um padre no deserto da dita pós-modernidade.

Em L'elogio della coscienza: la verità interroga il cuore, ele tenta demonstrar especialmente, em meio ao relativismo moral que caracteriza as sociedades ocidentais, qual é a função do papado. De fato, o papado é uma instituição não muito compreendida, como demonstrou o colega de cardinalato de Ratzinger, o teólogo Hans urs von Balthasar em seu livro $O$ complexo antirromano (não publicado no Brasil), que pergunta em uma de suas páginas se "não resulta inquietante que o complexo antirromano ou a contestação dirigida 
quase sempre contra o princípio petrino se consolide, se difunda e impere em vastos setores do mundo católico".

Frente à repulsa a qualquer tipo de autoridade, característica desses tempos já analisados pelo pensador espanhol José Ortega y Gasset em seu seminal A rebelião das massas, Bento XVI visa lembrar, nesse seu último livro, qual o significado do papado. Para isso, utiliza-se desta frase do famoso cardeal John Henry Newman, sacerdote anglicano inglês convertido ao catolicismo: "Certamente se eu tivesse de trazer a religião para um brinde depois do almoço - coisa que não é muito indicado fazer - então eu brindaria ao papa. Mas primeiro à consciência, depois ao papa." (tradução livre). Com essa assertiva, o cardeal visava minimizar as premissas da Igreja ultramontana nascente do século XIX que centralizava a autoridade no papado devido à emergência do liberalismo e suas consequências políticas - ao afirmar que se deve aceitar a autoridade do papa somente quando há o primado da consciência. Ratzinger utiliza-se dessa frase para afirmar, contra o subjetivismo moderno, que o indivíduo tem a "presença perceptível e imperiosa da voz da verdade" dentro de si e que "a consciência é a superação da mera subjetividade no encontro entre a interioridade do homem e a verdade que provém de Deus" (p.18).

Segundo Bento XVI, "a verdadeira natureza do ministério de Pedro tornou-se incompreensível no todo na época moderna precisamente porque nesse horizonte mental só se pode pensar a autoridade com categorias que não consentem mais alguma ponte entre sujeito e objeto". Ratzinger utiliza-se do conceito de anamnesis para falar da missão petrina. Como carregamos, supostamente, as "sementes do Verbo" em nossos corações, somos capazes do Bem, como nos fala Santo Agostinho. Mais ainda: somos capax Dei (capazes de Deus). Porém, essa capacidade não é tematizada, ela é experimentada como um sentimento interior, uma capacidade de reconhecimento. Para Bento XVI, a anamnesis infusa no nosso ser precisa de uma ajuda do exterior para tornar-se consciente de si. Aí está a função central do papa, uma função maiêutica, como lembra em algumas linhas a mensagem socrática. Mais do que diretivas da hierarquia, que vêm de cima para baixo, afirma Bento XVI, é a capacidade de orientação da memória da fé simples que leva ao discernimento dos espíritos. "Só em tal contexto se pode compreender corretamente o primado do papa e a sua correlação com a consciência cristã", nos diz. 
Tendo como pano de fundo essa compreensão de papado, Ratzinger, na primeira parte do livro - La dittatura del relativismo -, reflete sobre a busca de valores que protejam a dignidade humana, as funções do Estado moderno, o aborto, os métodos contraceptivos, os valores religiosos e morais na sociedade pluralista, as ideias de liberdade e democracia. Para tanto, cita autores como Hans Kelsen, Heinrich Schlier, Richard Rorty, Pierre Bayle, Norberto Bobbio, Karl Popper, Joseph Schumpeter e se utiliza de suas ideias.

$\mathrm{Na}$ breve segunda parte, intitulada Sulla ricerca della verità, Bento XVI apresenta seus pressupostos compreensivos e faz um percurso que vai da escuta, passando pela aceitação até chegar à resposta (ascoltare-accettare-rispondere), deixando claro que "a fé é antes de tudo aquela ordem da razão, sem a qual essa perde o seu critério e o juízo sobre seus próprios escopos" (p. 87).

Na terceira e última parte - Sulla evangelizzazione -, Ratzinger discorre sobre a vocação eclesial do teólogo, a nova evangelização, com suas estruturas, métodos e conteúdos essenciais e a questão da consciência moral. Este é um momento importante da obra, pois fazendo a ponte com a compreensão inicial do papado, Bento XVI fala sobre as missões do Magistério eclesiástico, a função do papa, dos bispos, em suma, do colégio episcopal.

Segundo ele, o Magistério tem "a tarefa de discernir, diante de juízos normativos para a consciência dos fiéis, os atos que são em si mesmos conformes às exigências da fé e promovem a expressão da vida, e aqueles que ao contrário, pela sua malícia intrínseca, são incompatíveis com essas exigências" (p. 102).

Para concluir, novamente reafirmamos a importância da obra em epígrafe para se compreender o pensamento de Bento XVI em suas linhas gerais, especialmente no que tange à consciência moral e à compreensão da missão do papado no mundo contemporâneo. 